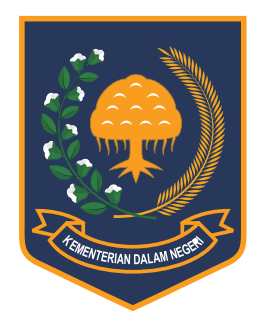

JURNAL BINA PRAJA

e-ISSN: 2503-3360 | p-ISSN: 2085-4323

Accreditation Number

21/E/KPT/2018

http://jurnal.kemendagri.go.id/index.php/jbp/index

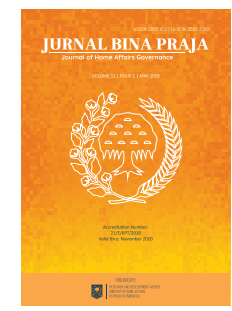

\title{
INFLUENCE OF IMPLEMENTATION OF DEVElopment AND SUPERVISION POLICY TO THE EFFECTIVENESS OF REGIONAL AUTONOMY IN INDONESIA
}

\author{
Hadi Prabowo* \\ Ministry of Home Affairs of the Republic of Indonesia \\ Jl. Medan Merdeka Utara No. 7, Jakarta Pusat
}

Received: 9 April 2019; Accepted: 9 May 2019; Published online: 31 May 2019

DOI: $10.21787 / \mathrm{jbp} .11 .2019 .63-73$

\begin{abstract}
The regional autonomy implemented for more than two decades is not entirely a success. An evaluation of the regional governance shows that many of the regional heads are tangled in legal cases, have bad financial management, and some other problems in the different levels of government. As such, it is necessary to examine the implementation of the development and supervision policy which aims to ensure the effectiveness of the regional autonomy. This study used a mixed, two stages method, with a quantitative approach using multiple regression analysis and followed by the qualitative approach of triangulation and ASOCA (Ability, Strength, Opportunities, Culture, and Agility) analysis method. The population in this study is the whole autonomous region in Indonesia (542 regions) with a sample of 85 regions. The quantitative analysis showed significant influence between the implementation of policy and development and supervision to the effectiveness of the regional autonomy. The qualitative analysis supported the quantitative analysis result and found new the dominant factors that produce a new model (novelty) called HADI (Human resources, Acceptance, Development, and Innovation) as an alternative model of the development and supervision policy for the effectiveness of regional autonomy. This study concluded that the successful implementation of an effective regional autonomy is very much influenced by the implementation of the policy and that a HADI model could be used as an alternative solution to the problem.
\end{abstract}

Keywords: Implementation of Policy, Development and Supervision, Effectiveness, Regional Autonomy.

\section{INTRODUCTION}

Government is formed with the intention to build a civilization and maintain its social order so that people can live a reasonable life. Indonesia as a unitary state has clearly defined the purpose of statehood as stated in the preamble to the 1945 Constitution. As a unitary state, Indonesia is comprised of provincial regions, and the provinces comprised of districts/cities. Every province, district, and city have its own regional government where it governed with regional autonomy and assistance tasks from the central government as regulated in the 1945 Constitution and Law Number 23 of 2014 on Regional Government (UndangUndang Republik Indonesia Nomor 23 Tahun 2014 tentang Pemerintahan Daerah, 2014).

Relating to the development and supervision policy from the Ministry of Home Affairs (MoHA) and the Ministry/Non-Ministry Government Institution (NMGI) on the implementation of regional autonomy policies, many of the central policies fail to be implemented on target in the regions. Some regions even implemented conflicting policies with the central policy. This problem is found in the business permits policy. Some regions hamper this policy by implementing complex requirements to obtain permits, causing a low Ease of Doing Business Index rank of 109 (Malaysia's rank is 18 and Thailand's rank is 49). There is also some lack of coordination between the MoHA and the MNGI, which often produce overlapping policies that cause the confusion of the regional governments.

This condition is highlighted by Yurniwati \& Rizaldi (2015) which state: "Good public

\footnotetext{
* Corresponding Author

Phone : +6281331805805

Email : hprabowo0904@gmail.com
} 
governance at the local government level became one of the central issues in Indonesia after the will that began with the issuance of Law No. 22 of 1999 as amended by Law No. 23 of 2014 on the Regional Government.". Kugonza \& Mukobi (2016) stated, "Participation, transparency, and accountability are widely acknowledged to be key pillars of good governance." Regional autonomy is the right, authority, and obligations of the autonomous region to control and manage its own household, and also has the objective to enhance the public service quality, promote democracy, improve national justice and regional equity, nurture the harmonious relationship between central and regional governments, encourage community empowerment, support community initiative and creativity, increase community participation, develop the role and function of the DPRD, and develop the regional economy. This is similar to Kitayama (2001) statement "Regional governments have been able to play the important roles in the delivery of public services and regional development as an integrated part of the overall government."

An evaluation of the implementation of regional government by the Directorate General of Regional Autonomy of MoHA in 2016-2018 also shows that regional autonomy implementation has many problems, one of which is the regional financial management. BPK founds that out of the 542 Financial Report of the Regional Government (LKPD), only 411 (76\%) received Unqualified Opinion (WTP), 113 (21\%) received Unqualified Opinion with an Explanatory Paragraph (WDP), and $18(3 \%)$ regions received Disclaimer of Opinion (TMP) as revealed by Aivanni (2018).

Regional autonomy is also not effective in the field of law. Based on the evaluation of the Directorate General of Regional Autonomy, several Regional Heads and Vice Heads were involved in legal cases. Three cases of misuse of authority and six cases of corruption in 2016. Five cases of misuse of authority and three cases of corruption in 2017. Fourteen cases of misuse of authority and twelve cases of corruption in 2018. Fourteen cases are still in the investigation process.

The regional autonomy provides the opportunity and freedom for the autonomous regions to responsibly taking care and manage the interests of its community, based on the aspirations of the community and implementing their own initiative in accordance with the laws and regulations. Hutauruk (2010): "In general the implementation of regional autonomy encourages District/City government to take creative steps to realize the vision and mission of the regional heads." Therefore, the implementation of regional autonomy should increase the level of development and culminates in the welfare of the people.

The greater decentralization after the Reformation era and the promulgation of Law Number 23 of 2014 is expected to create a more prosperous society which is closer to its government. This is in line with Abdulhamid \& Chima (2016) statement that "Regional governments are created with the ultimate goal of bringing the government closer to the people at the grassroots level." But this goal seems to be still far from reality. This can be seen from the increasing economic gap in Indonesia based on an evaluation of the Directorate General of Regional Finance of MoHA in 2016-2018, where Indonesia's GINI coefficient increased from 0.33 to 0.41 . the highest in history. This shows that the decentralization system, which originally aimed to distribute the economic prosperity to the regions and not only concentrated in Java and Sumatra, does not succeed to bring a maximum impact.

The implementation of regional autonomy is not effective because the role of the MoHA as the coordinator for the regional governments is still not optimum and comprehensive. One of the reasons for this is the lack of coordination with the other Ministries/Non-Ministry Government Institutions, which result in overlapping regulations for regional programs and activities. But many also stem from the ineffectiveness of components in MoHA in performing their own roles.

As expressed by Badara \& Saidin (2013) "Providing a proper control environment for regional government is essential to the effectiveness of their operation." As stated by Akizuki (2001), "Controlled decentralization has kept the overall administrative system stable while accommodating the rising needs and capabilities of the regional governments."

Based on the current condition of the regional autonomy in Indonesia, this study is strategic and in accordance with the latest regulations. There is a need to examine the implementation of the development and supervision policy to the effectiveness of regional autonomy in Indonesia, based on Law Number 23 of 2014 on Regional Government and Government Regulation Number 12 of 2017 on the development and supervision of the implementation of the regional government. The study location was all Provincial, District and Cities in Indonesia.

Based on the evaluation and the information gathered, the was a gap between the central government's policy on regional autonomy with its implementation in the regions. This also shows that the government is less effective in developing and supervising the effectiveness of the implementation 
of regional autonomy.

From these situations, we formulate the study problem as follows (1) How much the implementation of the policy influences the effectiveness of the regional autonomy in Indonesia? 2) How much the implementation of development and supervision policy influenced the effectiveness of the regional autonomy in Indonesia? 3) How much the implementation of both the development and supervision policy influenced the effectiveness of the regional autonomy in Indonesia?

In addition, this study also uses the qualitative approach with the focus of the problem of (4) What is the proper model for the implementation of the development and supervision policy to ensure the effectiveness of the regional autonomy in Indonesia?

The background of this study are all problems on the implementation of the development and supervision policy on regional autonomy by the $\mathrm{MoHA}$ as the coordinator of the regional governance in Indonesia.

\section{Method}

This study used the mixed methods described by Sugiyono (2014). Next, the researchers chose to use the Sequential Explanatory Design described by Creswell (2018, p. 211) where through sequential explanatory design further qualitative data is collected and analyzed to explain and interpret the findings from the quantitative phase.

This study used a quantitative approach with the population of 542 regions and the stratified random sampling of 85 samples, which were comprised of five provinces (Riau Islands, East Java, West Kalimantan, Southeast Sulawesi, West Papua), 65 districts and 15 cities. The questionnaires were disbursed to ten people in each sample, which bring the total number of 850 questionnaires. The questioners were disbursed to all the sample areas in the meeting of the districts and cities at the provincial level. The phenomenon was tested with statistical procedures between the theory and empirical fact from each variable, to find the relationship and the influence of the policy implementation variables (X1) and the development and supervision (X2) to regional autonomy effectiveness variable (Y). Questionnaires were used in the collection of data and information from the respondents. The hypothesis of this study is (1) the implementation of the policy has a significant influence on the effectiveness of regional autonomy in Indonesia. 2) The development and supervision policy have a significant influence on the effectiveness of regional autonomy in Indonesia. 3) The implementation of both the policy and the development and supervision have a significant influence on the effectiveness of the regional autonomy in Indonesia.

The operational variables consist of Policy Implementation variable as described by Edwards (2008, p. 171) with the dimensions of Communication, Resources, Executive Attitude, and the Bureaucracy Structure. The development and supervision variable as described by Terry (2013, p. 221), with the dimensions of the general Development and Supervision, Standard Assignment, Measurement of Activities, Comparison between the Activities and the Standard, Corrective Action. And the Effectiveness variable by Campbell (1989, p. 71) with the dimension of Success of the Program, Achievement of Target, Satisfaction Toward the Program, Output and Input Levels, and Achievement of the Overall Target.

The qualitative analysis to answer the problem number (4) of this study was by triangulation approach. Data collected through interview, focus group discussions and observations and then analyzed by inductive analysis method. The key sources were the Regional Head/Vice Head, the Head of the Development Planning Agency at Regional Level (Bappeda) and the Head of the Regional Inspectorate. It was conducted during the meetings of districts and the cities at the provincial level. The researchers used the Ability, Strength, Opportunities, Culture, and Agility (ASOCA) method by Suradinata (2016, p. 18) to obtain the strategy for the implementation of the development and supervision policy.

\section{RESULTS AND DISCUSSION}

The researchers divided the discussion into two parts, one discussed the results of the quantitative study and another to present and discuss the results of the qualitative study.

\section{A. Results and Discussion of the Quantitative Study}

Each of the 850 respondents stated their opinion for each statement in the questionnaire on each variable of the study. The researcher used the Likert Scale as the measurement.

The validity and reliability test were performed on the questionnaire. The validity index was calculated using the product moment correlation. A statement was deemed as valid if its coefficient of correlation was greater than 0.30 or its significance value was smaller than $\propto 0,05$.

The calculation of the validity of the questionnaire's reply $(14$ items of policy implementation variables, 22 items of development and supervision variables, and 14 items of the 
Table 1.

Results of the Reliability Test of the Questionnaire Variable

\begin{tabular}{clccc}
\hline No. & Variables & $\begin{array}{c}\text { Number of } \\
\text { the State- } \\
\text { ments }\end{array}$ & $\begin{array}{c}\text { Reliability } \\
\text { Coefficient }\end{array}$ & Descriptions \\
\hline 1 & 14 & 0.970 & Reliable \\
\hline $\begin{array}{l}\text { The implemen- } \\
\text { tation of the } \\
\text { Policy (X1) }\end{array}$ & 22 & 0.965 & Reliable \\
\hline $2 \quad \begin{array}{l}\text { Development } \\
\text { and Supervision } \\
\text { (X2) }\end{array}$ & & 0.918 & Reliable \\
\hline $3 \quad \begin{array}{l}\text { The Effective- } \\
\text { ness of the } \\
\text { Regional Auton- } \\
\text { omy (Y) }\end{array}$ & 14 & & \\
\hline
\end{tabular}

effectiveness of regional autonomy variables) produced correlation coefficient of greater than 0.30 with its significance value smaller than $\propto$ 0,05 . As such, it can be concluded that the items are valid. Thus, the entire items on the statements of this study are valid.

Next, a reliability test, the Alpha Cronbach method, was conducted to measure the reliability of the variables in the questionnaire. The questionnaire is reliable when its coefficient is more than 0.70 (Barker, Pistrang, \& Elliott, 2002, p. 70).

The reliability test shows that each variable of the study has a reliability coefficient of $>0.70$. As such, the statements on all variables was concluded to be reliable.

The relationship between the variables is said to have a significant correlation if the correlation analysis produces a correlation value of more than 0.3 or the significance value is smaller than $\propto 0.05$.

Table 2 shows that the correlation coefficient between the policy implementation variables (X1) and the effectiveness variable (Y) is 0.602 , with the significance level of 0.000 . This indicates that there is a significant correlation between variable $\mathrm{X} 1$ to variable $Y$. The table above also shows a correlation between the development and supervision variable (X2) to the effectiveness variable (Y) with the correlation coefficient of 0.764 and the significance level of 0.000 , indicating that there is a significant correlation between variables $\mathrm{X} 2$ to variable $\mathrm{Y}$.

Next, a linear regression analysis was conducted. The regression equation was:

$$
Y=-3.165+0.346 X 1+0.459 X 2
$$

Table 3 shows that the regression coefficient between the Policy Implementation (X1) and the development and supervision (X2) has a positive value. This means that the implementation of the Development and Supervision has a linear influence toward improving the effectiveness of the Regional Autonomy. Policy Implementation (X1) has a positive regression coefficient of 0.346 while the development and supervision (X2) has a positive Regression Coefficient of 0.459 .

The linear regression equation was obtained from the Normality test, the Multicollinearity test,

Table 2.

Correlation between Independent Variables to the Dependent Variables

\begin{tabular}{|c|c|c|c|c|}
\hline & & $\begin{array}{l}\text { Implementation } \\
\text { of the Policy }\end{array}$ & $\begin{array}{l}\text { Development } \\
\& \text { Supervision }\end{array}$ & Effectiveness \\
\hline \multirow{3}{*}{$\begin{array}{l}\text { Implementation } \\
\text { of the Policy }\end{array}$} & Pearson Correlation & 1 & $.464 * *$ & $.602 * *$ \\
\hline & Sig. (2-tailed) & & .000 & .000 \\
\hline & $\mathrm{N}$ & 850 & 850 & 850 \\
\hline \multirow{3}{*}{$\begin{array}{l}\text { Development } \\
\& \text { Supervision }\end{array}$} & Pearson Correlation & $.464^{* *}$ & 1 & $.764 * *$ \\
\hline & Sig. (2-tailed) & .000 & & .000 \\
\hline & $\mathrm{N}$ & 850 & 850 & 850 \\
\hline \multirow{3}{*}{ Effectiveness } & Pearson Correlation & $.602 * *$ & $.764^{* *}$ & 1 \\
\hline & Sig. (2-tailed) & .000 & .000 & \\
\hline & $\mathrm{N}$ & 850 & 850 & 850 \\
\hline
\end{tabular}


Table 3.

The Results of the Regression Analysis

\begin{tabular}{|c|c|c|c|c|c|c|}
\hline \multicolumn{7}{|c|}{ Coefficients } \\
\hline \multicolumn{3}{|c|}{$\begin{array}{l}\text { Unstandardized } \\
\text { Coefficients }\end{array}$} & \multicolumn{2}{|r|}{$\begin{array}{l}\text { Standardized } \\
\text { Coefficients }\end{array}$} & \multirow{2}{*}{$\mathbf{t}$} & \multirow{2}{*}{ Sig. } \\
\hline Model & & B. & Std. Error & Beta & & \\
\hline \multirow[t]{3}{*}{1} & (Constant) & $-3,165$ & 1,276 & & $-2,480$ & .013 \\
\hline & X1 (Impl. Policy) & .346 & .025 & .315 & 13,972 & .000 \\
\hline & X2 (Binwas) & .459 & .017 & .618 & 27,443 & .000 \\
\hline
\end{tabular}

a. Dependent variables: $Y$ (the effectiveness of the Implementation of Regional Autonomy)

and the Heteroscedasticity test. The Normality tests in this study were using the KolmogorovSmirnov Test approach and the graph method. This test shows if the residual data has a normal distribution or not. Data has a normal distribution if the significance level is $>0.05$.

The One-Sample Kolmogorov-Smirnov Test produced the Test Statistic of 0.031 with Asymp.Sig (2-tailed) of 0.057 . The calculation shows that the level significance is more than 0.05 , the conclusion is that the error term of the regression model has a normal distribution, which means that the study's data are assumed to be normal.

Multicollinearity tests show that the independent variables in the regression model perfectly correlate. This shows that the regression equation does not explain the influence of $\mathrm{X}$ to $Y$. The multicollinearity can be seen from the VIF (Variance Inflation Factors) value. The high collinearity is obtained if the VIF value for the independent variables is greater than 10 .

The calculation shows that the VIF value for each of the study variables were less than 10 , as such, it can be stated that there was no multicollinearity on the regression model.

Table 4.

The Coefficient of Determination of $\mathrm{X}$ to $\mathrm{Y}$

\begin{tabular}{llllc}
\hline \multicolumn{5}{c}{ Summary Model } \\
\hline Model & $\mathbf{R}$ & R Square & $\begin{array}{c}\text { Adjusted } \\
\text { R Square }\end{array}$ & $\begin{array}{c}\text { Std. Error } \\
\text { of the Estimate }\end{array}$ \\
\hline 1 & .814 & .662 & .661 & 4.95117 \\
\hline - Predictors: (Constant), X2 (Binwas), X1 (Implementation of the \\
Policy)
\end{tabular}

The Heteroscedasticity test is testing whether there is different variability from one residual observation to another in the regression model. The researcher found that in this study, the scatterplot graph does not show a particular pattern or form, dots were spread in random order and data spread evenly on the X-axis and on the Y-axis. Therefore, it can be concluded that there was no heteroscedasticity in the linear regression model.

From the three tests on the regression assumptions (the normality test, the multicollinearity test, and the heteroscedasticity test), it and can be concluded that the three test results met the classical regression assumptions and thus the linear regression equation can be said to be good.

Table 5.

The Partial Coefficient of Determination of X - Y

\begin{tabular}{|c|c|c|c|c|c|}
\hline \multicolumn{6}{|c|}{ Coefficients } \\
\hline & \multirow{2}{*}{ Model } & Standardized & \multicolumn{3}{|c|}{ Correlations } \\
\hline & & Beta & $\begin{array}{l}\text { Zero } \\
\text {-order }\end{array}$ & Partial & Part \\
\hline 1 & (Constant) & & & & \\
\hline & $\begin{array}{l}\text { X1 } \\
\text { (Implementation } \\
\text { of the Policy) }\end{array}$ & .315 & .602 & .433 & .279 \\
\hline & $\begin{array}{l}\text { X2 } \\
\text { (Development } \\
\text { and Supervision) }\end{array}$ & .618 & .764 & .686 & .548 \\
\hline
\end{tabular}

- Dependent variables: $Y$ (the effectiveness of the Implementation of Regional Autonomy) 
The next step is to calculate the coefficient of determination for the influence of both policy implementation and the development and supervision to the effectiveness of the Regional Autonomy.

The calculation shows correlation values (R) of 0.814 . It can be concluded that the relationship between the implementation of both the policy and the development and supervision to the effectiveness of the Regional Autonomy is very strong. The value of $\mathrm{R}$ square from the SPSS calculation described in table 9 is 0.662 . This means that the implementation of the policy together with the development and supervision has a 66.2 percent influence on the effectiveness of the Regional Autonomy and the other 33.8 percent is influenced by other factors that are not observed in this study.

The influence of the policy implementation to the effectiveness of the Regional Autonomy is $=0.315 \times 0.602=0.189$. This means that the implementation of the policy influences the effectiveness of Regional Autonomy by 18.9 percent. The influence of the development and supervision to the effectiveness of the Regional Autonomy is $=0.618 \times 0.764=0.473$. This means that the implementation of development and supervision influence the effectiveness of the implementation of Regional Autonomy by 47.3 percent. It can be concluded that the $\mathrm{X} 2$ variables (the implementation of development and supervision) has more influence on the dependent variables $Y$ (the effectiveness of Regional Autonomy) when compared with the variables X1 (Policy Implementation).

Next steps were testing the proposed hypothesis. The first hypothesis test is simultaneously testing the influence of variable $\mathrm{X}$ to variable $\mathrm{Y}$. The $\mathrm{F}$ test is used to test the overall regression coefficient to see the overall significance of the relationship between the independent and the dependent variables. The hypotheses were:

Ho: $\beta 1, \beta 2=0$ The implementation of both the policy and the development and supervision do not influence the effectiveness of Regional Autonomy.

Ha $: \beta i \neq 0 \quad$ The implementation of both the policy and the development and supervision influence the effectiveness of Regional Autonomy.

As shown in the table, the $F_{\text {value }}$ is 830.427 with 0.000 significance. The $F_{\text {value }}$ was compared
Table 6.

The Simultaneous Test Results (F-test)

\begin{tabular}{|c|c|c|c|c|c|c|}
\hline \multicolumn{7}{|c|}{ ANOVA } \\
\hline & Model & $\begin{array}{c}\text { Sum } \\
\text { of Squares }\end{array}$ & df & $\begin{array}{l}\text { Mean } \\
\text { Square }\end{array}$ & $\mathbf{F}$ & Sig. \\
\hline \multirow[t]{3}{*}{1} & Regression & 40714.272 & 2 & 20357.136 & 830.427 & $.000 \mathrm{~b}$ \\
\hline & Residual & 20763.409 & 847 & 24,514 & & \\
\hline & Total & 61477.681 & 849 & & & \\
\hline \multicolumn{7}{|c|}{$\begin{array}{l}\text { - Dependent variables: } \mathrm{Y} \text { (the effectiveness of Regional } \\
\text { Autonomy) }\end{array}$} \\
\hline
\end{tabular}

with the $\mathrm{F}_{\text {table }}$ to test the hypothesis. The value of Ftable with $\mathrm{db} 1=2$ and $\mathrm{db} 2=850-2-1=847$ are 3.006. The $F_{\text {value }}$ of 830.427 , is greater than the $F_{\text {table }}$ of 3.006 and significant value (p-value) of 0.000 is smaller than $\alpha=0.05$. It can be decided that $\mathrm{HO}$ is rejected on $\alpha=0.05$. As such, it can be concluded that the implementation of both the development and supervision policy influenced the effectiveness of Regional Autonomy.

The next hypothesis test was used to determine whether or not there is a tangible impact from either implementation of a policy or the development and supervision to the effectiveness of the Regional Autonomy. This influence was tested using the t-test method. The determination of the acceptance or rejection of $\mathrm{HO}$ is conducted by comparing the $t_{\text {count }}$ with $t_{\text {table }}$ or from the value of its significance.

The $t_{\text {table }}$ shows that the value of $t_{\text {table }}$ for $\alpha=$ 0.05 and degrees of freedom (df) $=850-2-1=$ 847 on two-sided testing are 1,963.

The t-test from the table of the regression coefficient for the Implementation variable (X1) is 13,972 with the value of the significance of

Table 7.

The Partial Test Results (t-test)

\begin{tabular}{ccccccc}
\hline $\begin{array}{c}\text { The Hy- } \\
\text { pothe- } \\
\text { sis }\end{array}$ & t-count & Sig (p) & t-table & $\alpha$ & $\begin{array}{c}\text { Deci- } \\
\text { sion }\end{array}$ & $\begin{array}{c}\text { De- } \\
\text { scrip- } \\
\text { tions }\end{array}$ \\
\hline $\begin{array}{c}\mathrm{H} 0: \\
\beta 1=0\end{array}$ & 13.972 & 0.000 & 1.963 & $5 \%$ & $\begin{array}{c}\text { HO } \\
\text { Reject- } \\
\text { ed }\end{array}$ & $\begin{array}{c}\text { Signifi- } \\
\text { cant }\end{array}$ \\
\hline $\begin{array}{c}\mathrm{H} 0: \\
\beta 2=0\end{array}$ & 27.443 & 0.000 & 1.963 & $5 \%$ & $\begin{array}{c}\text { HO } \\
\text { Reject- } \\
\text { ed }\end{array}$ & Signifi- \\
cant
\end{tabular}


0,000 . The value of tcount of $=13,972$ is greater than the value of $t_{\text {table }}$ of $1,963(13,972>1,963)$, as such, based on the test results, H0 is rejected. The significance value of the test is 0,000 smaller than 0.05. As such, the test is significant. Based on the test results, it can be concluded that the Policy Implementation positively influences the effectiveness of Regional Autonomy.

Next, for the Development and Supervision (X2) variable, the result of the t-test from the regression coefficient table shows the value of 27.443 with the significance value of 0.000 The value of $t_{\text {count }}=27.443$ is greater than the value of $t_{\text {table }}=1,963(27,443>1,963)$, as such, based on the test results, $\mathrm{H} 0$ is rejected. The significance value of 0.000 is smaller than 0.05 . As such, the test was significant. Based on the test results, it can be concluded that the development and supervision influence the effectiveness of Regional Autonomy.

Based on the multiple regression analysis, the regression equation for the influence of the implementation of both the policy and the development and supervision to the effectiveness of Regional Autonomy is $\mathrm{Y}=-3.165+0.346 \mathrm{X} 1+$ $0.459 \mathrm{X} 2$. The result shows that the regression coefficient of the Policy Implementation and the Development and Supervision has positive values. This means that the better the policy implementation and the better development and supervision will increase the effectiveness of Regional Autonomy.

The correlation coefficient of 0.814 indicates that there is a very strong relationship between the Policy Implementation and the Development and Supervision to the effectiveness of Regional Autonomy. The Policy Implementation and the Development and Supervision has a 66.2 percent influence on the effectiveness of the Regional Autonomy and the other 33.8 percent is influenced by other factors that are not observed in this study. The F-test shows that there is a meaningful influence (significant) of simultaneous implementation of both the policy and the development and supervision to the effectiveness of the Regional Autonomy. Fcount of 830.427 is greater than the $\mathrm{F}_{\text {table }}$ of 3.006 and significance value ( $p$-value) $<0.05$.

The t-test results (partial test) for the influence of Policy Implementation shows the significant value of $0.000<0.05$, as such, the test results are significant. Policy Implementation positively influences the effectiveness of Regional Autonomy. The value of predictors coefficient for the Policy Implementation variable of 0,346 means that the average effectiveness difference will increase by 0.346 if the Policy Implementation rose by one unit while the Development and Supervision variable remains the same. Policy Implementation influences the effectiveness of Regional Autonomy by 18.9 percent.

The Development and Supervision variable shows have a significance value of $0.000<0.05$, as such, the test results are significant. The value of predictors coefficient for the Development and Supervision variable of 0.459 means that the average effectiveness difference will increase by 0.459 if the Development and Supervision variable rose by one unit while the Policy Implementation variable remains the same. Development and Supervision positively influence the effectiveness of Regional Autonomy. The implementation of Development and Supervision influence the effectiveness of Regional Autonomy by 47.3 percent.

\section{B. Results and Discussion of the Qualitative Study}

This study used the triangulation approach and ASOCA analysis method. Based on the triangulation approach, the qualitative analysis shows that the effectiveness of regional autonomy can be good when the Development and Supervision policy is also well implemented. The result of the triangulation approach supports the result of the quantitative analysis, that there is a strong influence between the effectiveness of regional autonomy and the implementation of the Development and Supervision policy.

ASOCA analysis (Ability (capability), Strength (power) Opportunities (chance), Culture (culture), and Agility (intelligence) was used to analyze the regional government's governance to find a decision-making strategy for the implementation of development and supervision policies to ensure the effectiveness of the regional autonomy. The ASOCA method was selected because this method has been widely used by the alumni the National Defense Institutions (Lemhanas) (Suradinata, 2016, p. 17)). The ASOCA analysis was used to gain further understanding of the quantitative analysis, by performing in-depth analysis and finding the dominant factors in the implementation of development and supervision policy for the effectiveness of regional autonomy.

\section{1) Ability}

Ability analysis, as described by Suradinata (2016, p. 18), derived from the word "able" which means the power (can, able) to do something. It can also be interpreted as the ability, skill, and capability. 
Based on the Ability Analysis the dominant factors are: Human resource capability as the implementer of the development and supervision policies, Acceptance of the central government's development and supervision programs by the provincial government and subsequently to district/ city governments, Development ability to enhance the programs, as well as the ability to Innovate in the development and supervision program to drive the effectiveness of regional autonomy.

\section{2) Strength}

Strength is a driving factor and forces that come from within the organization. It includes all components of the organization (resources and capabilities) that can be optimized to positively influence the organizational development or the implementation of a work program.

Based on the Strength Analysis, the dominant factors are: the strength of human resource who can push for the implementation of the policy, the power of acceptance from both parties to push for implementation the policy, the power of development to enhance the development and supervision programs, as well as the power of Innovation to drive the effectiveness of regional autonomy.

\section{3) Opportunities}

Opportunities are to look at the forces outside the organization, in this case, it looks at the opportunities for the implementation of development and supervision policies (Özşahin, Zehir, Acar, \& Sudak, 2013). Based on the analysis of opportunities on the implementation of development and supervision policies, the dominant factors were: the opportunity for Human resources in implementing the development and supervision policies, the opportunity for Acceptance of the development and supervision programs by the provinces and districts/cities, the opportunity for Development to enhance the development and supervision programs, and the opportunity to Innovate in the development and supervision programs.

\section{4) Culture}

For Robbins \& Judge (2013, p. 261), an organization's culture is defined as the basic philosophy that gives direction for the policy of the organization in managing its resources. Based on the analysis of culture for the implementation of development and supervision policies, the dominant factors were: the organization's culture for human resources in implementing the development and supervision policies, the acceptance culture of the implementation of the development and supervision programs, the culture for the enhancement of the development and supervision programs can be implemented, and the culture of innovation to innovate in the development and supervision programs.

\section{5) Agility (intelligence)}

In Consulting Psychology Journal: Practice and Research, De Meuse (2017) stated: "High-learning agile individuals take 'the right lessons' from their experiences and apply the lessons to new situations. Those who have 'high-learning agility' seek for a new challenge, actively seek feedback from other people to develop and grow himself, tend to selfreflect, and evaluate their experiences and draw practical conclusions."

Based on the analysis of agility towards the implementation of development and supervision policies, the dominant factors are: Human resources' intelligence to take the right lessons and applies them, social intelligence from the central and provincial governments and districts/cities for the acceptance of the program, social intelligence for the enhancement of development and supervision programs, as well as social intelligence in the form of innovation to innovate in the development and supervision programs.

The ASOCA Qualitative analysis described above focuses on the implementation of the Development and Supervision Policy for Regional Autonomy effectiveness. The result was then used to obtain the dominant factors, which was the novelty of this study. The dominant factors can be utilized as the solution for a successful implementation of the development and supervision policy for regional autonomy effectiveness. This dominant factor is HADI (Human resources, Acceptance, Development, and Innovation). These four dimensions might be one of the dominant factors in the implementation of the development and supervision policy.

\section{a) Human Resources}

This study found elements of the human resources that are an integral part of the successful implementation of the development and supervision policy for effective regional autonomy. Both quantitative and qualitative analysis of this study found very strong and dominant factors affecting the successful implementation of the development and supervision policy for an effective regional autonomy. The quantitative analysis variable with a significant influence is found to be highly depending on the 
role of human resources. The Ability Analysis found the dominance of the role of the human resources in the successful implementation of development and supervision policy.

This finding is in line with the opinion of Dessler (2013, p. 658), Mathis \& Jackson (2007, p. 78), and Siagian (2009, p. 57), on the concept of human resources.

Based on the analysis results stated earlier, it can be concluded that human resources are a dominant factor for the successful implementation of guidance and supervision policies to influence the effectiveness of regional autonomy.

\section{b) Acceptance}

The implementation of development and supervision policy is two-way programs and activities between the implementor of the policy and the party accepting the implementation. There are also two parties, the one who perform the development and supervision and another who accept the development and supervision. Both sides will interact with each other to agree on a specific substance.

The quantitative analysis showed that there was a significant influence between variable $\mathrm{X}$ and $\mathrm{Y}$, which showed acceptance between variable $X$ and $Y$. In the qualitative analysis, it was also found that for an effective regional autonomy, the acceptance between the party performing the development and supervision policy and the party receiving it is a dominant factor.

The finding on acceptance factor is in line with the opinion of Davis on acceptance (Davis, 1989).

From the above analysis, it can be concluded that acceptance is a very strong and dominant factor in the implementation of development and supervision policy influencing the effectiveness of regional autonomy.

\section{c) Development}

The results of the quantitative study show that the implementation of the Development and Supervision Policy was in need to be developed further. The qualitative analysis also further strengthens the existence of development as the dominant factor in

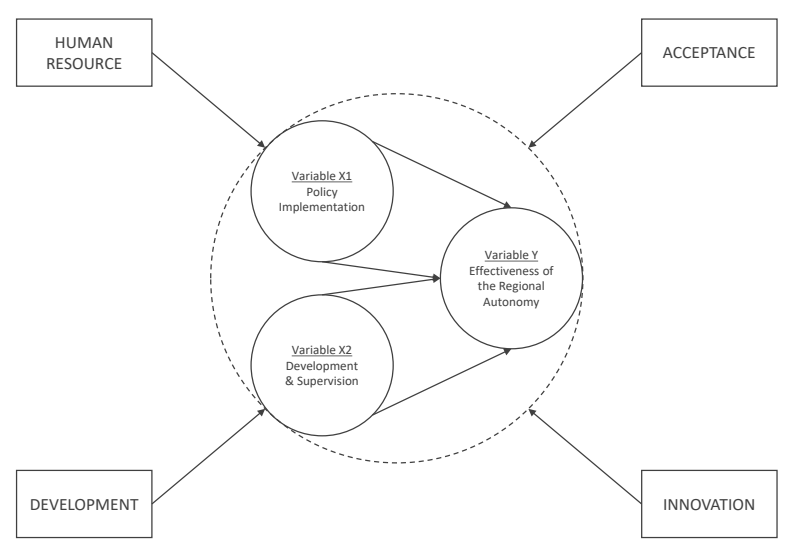

Figure 1. HADI Analysis Model

the implementation of the policy. This is due to the fluid changes and increase of complexity in the regional autonomy. Therefore, the Development and Supervision policy also should continue to develop.

This finding is in line with the theory of the development by Tjokroamidjojo (2000) and Siagian (2014, p. 212).

Based on the above analysis, it can be concluded that development is a dominant factor in the implementation of development and supervision policy influencing the effectiveness of regional autonomy.

\section{d) Innovation}

The quantitative analysis indicates that there is a significant influence of the implementation of development and supervision policy to the effectiveness of regional autonomy. It indicates the need for continuous update and added value in the implementation of development and supervision. Regional autonomy requires continuous improvement and value added from the development and supervision programs and not just a routine program without any considerations of the changes in the region.

Qualitative analysis strengthens the finding of innovation as the dominant factor, improvement and value added is always needed in the implementation of development and supervision policy for regional autonomy effectiveness.

This finding on innovation is in line with the theory of innovation described by the OECD in Naranjo-Valencia, JiménezJiménez, \& Sanz-Valle (Naranjo-Valencia, 
Jiménez-Jiménez, \& Sanz-Valle, 2016) and Osborne \& Brown (2005, p. 37).

From the above analysis, it can be concluded that innovation is a dominant factor that can influence the successful implementation of development and supervision policy influencing the effectiveness of regional autonomy in Indonesia.

The HADI model is presented as the implication and novelty of the study on the Influence of Implementation on the Development and Supervision Policy for the Effectiveness of Regional Autonomy, as presented in Chart 1.

\section{ConClusion}

Based on the analysis results, the study concluded that: (1) The Policy Implementation has a meaningful and significant influence on the effectiveness of Regional Autonomy. Better implementation of the policy results in more effective regional autonomy. (2) Development and Supervision have a meaningful and significant influence on the effectiveness of Regional Autonomy. Better development and supervision results in more effective regional autonomy. (3) The Policy Implementation together with Development and Supervision have a meaningful and significant influence on the effectiveness of Regional Autonomy. Better Policy Implementation, Development and Supervision results in more effective regional autonomy, and vice versa. (4) ASOCA analysis shown that good policy implementation and development and supervision results in an effective regional autonomy. The dominant factors are (1) human resources with optimum competency and capability, and also the durability and strength of running the program; (2) acceptance and good communication between the parties implementing and receiving the policy, the development and supervision; (3) expansion and development efforts that are always focus and strive for the improvement of regional autonomy. (4) Innovation as a breakthrough and acceleration of the development and supervision implementation to ensure the effectiveness of regional autonomy.

The four dominant factors are the new findings resulting from this study and are incorporated into the HADI (Human Resources, Acceptable, Development, and Innovation) concept. Further studies are therefore recommended to develop the Development and Supervision Model to ensure the effectiveness of regional autonomy.
An important and new finding from this study was the understanding that implementation of the policy should consider all of the dominant factors as a whole. A Ministerial regulation on the development and Supervision is needed, and it is necessary to set the Ministry of Home Affairs as the axis of government with its role in developing and supervising the implementation of comprehensive regional governance.

\section{ACKNOWLEDGMENT}

I would like to thank and give the highest appreciation to Prof. Dr. Ermaya Suradinata, Prof. Dr. Murtir Jeddawi, and dr. Sampara Lukman as the promoter and co-promoter of the scientific articles which we put in this journal.

I would also like to thank all the lecturers and the dissertation examiners team for their knowledge and counsels; the working team, A. Fatoni, Firm N, Taufiq M, and all parties that always faithful and eager to support the writing of this scientific article.

\section{REFERENCES}

Abdulhamid, O.-S., \& Chima, P. (2016). Local government administration in Nigeria: the search for relevance. Commonwealth Journal of Local Governance, (18), 181-195. https://doi. org/10.5130/cjlg.v0i18.4850

Aivanni, N. (2018, October 2). 512 Laporan Keuangan Pemerintah Pusat dan Daerah Dapat Opini WTP. Retrieved from Mediaindonesia. com website: https://mediaindonesia.com/ read/detail/187979-512-laporan-keuanganpemerintah-pusat-dan-daerah-dapat-opiniwtp

Akizuki, K. (2001). Controlled Decentralization: Local Governments and the Ministry of Home Affairs in Japan. Retrieved from http://siteresources. worldbank.org/WBI/Resources/wbi37170. pdf

Badara, M. S., \& Saidin, S. Z. (2013). Impact of the Effective Internal Control System on the Internal Audit Effectiveness at Local Government Level. Journal of Social and Development Sciences, 4(1), 16-23. Retrieved from https://amhinternational.com/journal/ index.php/jsds/article/view/731

Barker, C., Pistrang, N., \& Elliott, R. (2002). Research Methods in Clinical Psychology: An Introduction for Students and Practitioners. John Wiley \& Sons.

Campbell, J. P. (1989). Riset dalam Efektivitas Organisasi. Jakarta: Erlangga.

Creswell, J. W. (2018). Research Design: Qualitative, Quantitative, and Mixed Methods Approaches. 
SAGE Publications, Inc.

Davis, F. D. (1989). Perceived Usefulness, Perceived Ease of Use, and User Acceptance of Information Technology. MIS Quarterly, 13(3), 319. https:// doi.org/10.2307/249008

De Meuse, K. P. (2017). Learning agility: Its evolution as a psychological construct and its empirical relationship to leader success. Consulting Psychology Journal: Practice and Research, 69(4), 267-295. https://doi.org/10.1037/ cpb0000100

Dessler, G. (2013). Human Resource Management (13th ed.). Pearson Education, Inc.

Edwards, G. C. (2008). Implementing Public Policy. Congressional Quarterly Press.

Hutauruk, T. R. (2010). Tinjauan Daya Inovasi Pemerintah Daerah dalam Pelaksanaan Desentralisasi di Kabupaten/Kota Provinsi Kalimantan Timur.Jurnal Borneo Administrator, 6(3). https://doi.org/10.24258/jba.v6i3.66

Kitayama, T. (2001). Local government policy initiatives in Japan (English). Retrieved from http://documents.worldbank.org/ curated/en/784741468262523638/Localgovernment-policy-initiatives-in-Japan

Kugonza, S., \& Mukobi, R. (2016). Public participation in services delivery projects in Buikwe District Local Government Uganda. Commonwealth Journal of Local Governance, (18), 127-146. https://doi.org/10.5130/cjlg.v0i18.4846

Mathis, R. L., \& Jackson, J. H. (2007). Manajemen Sumber Daya Manusia (2nd ed.). Jakarta: Salemba Empat.

Naranjo-Valencia, J. C., Jiménez-Jiménez, D., \& SanzValle, R. (2016). Studying the links between organizational culture, innovation, and performance in Spanish companies. Revista
Latinoamericana de Psicología, 48(1), 30-41. https://doi.org/10.1016/j.rlp.2015.09.009

Osborne, S. P., \& Brown, K. (2005). Managing Change and Innovation in Public Service Organizations. New York: Psychology Press.

Özşahin, M., Zehir, C., Acar, A. Z., \& Sudak, M. K. (2013). The Effects of Leadership and Market Orientation on Organizational Commitment. Procedia - Social and Behavioral Sciences, 99, 363-372. https://doi.org/10.1016/j. sbspro.2013.10.504

Robbins, S. P., \& Judge, T. A. (2013). Organizational Behavior (15th ed.). Pearson Education, Inc.

Siagian, S. P. (2009). Manajemen Sumber Daya Manusia. Jakarta: Bumi Aksara.

Siagian, S. P. (2014). Administrasi Pembangunan: Konsep, Dimensi, dan Strateginya. Jakarta: Bumi Aksara.

Sugiyono. (2014). Metode Penelitian Manajemen. Bandung: Alfabeta.

Suradinata, E. (2016). Analisis Kepemimpinan Strategi Pengambilan Keputusan. Jatinangor: Alqaprint.

Terry, G. R. (2013). Prinsip-prinsip Manajemen. Bumi Aksara.

Tjokroamidjojo, B. (2000). Good Governance: Paradigma Baru Manajemen Pembangunan. Lembaga Administrasi Negara.

Undang-Undang Republik Indonesia Nomor 23 Tahun 2014 tentang Pemerintahan Daerah., Pub. L. No. 23 (2014).

Yurniwati, \& Rizaldi, A. (2015). Control Environment Analysis at Government Internal Control System: Indonesia Case. Procedia - Social and Behavioral Sciences, 211, 844-850. https://doi.org/10.1016/j. sbspro.2015.11.111 